\title{
Deep Ecology: A Framework for Sustainable Living in Thomas Coraghessan Boyle's A Friend of the Earth
}

\author{
S. Priya Dharsini
}

Ph. D Research Scholar in English, Sri Sarada College for Women(A), Salem - 16, India

Received: 10 Sep 2021; Received in revised form: 15 Oct 2021; Accepted: 24 Oct 2021; Available online: 31 Oct 2021

C2021 The Author(s). Published by Infogain Publication. This is an open access article under the CC BY license

(https://creativecommons.org/licenses/by/4.0/).

\section{"Look deep into Nature and then you will understand everything better" - Albert Einstein}

\begin{abstract}
Climate Change is certainly one of the most pressing human problems of today. With rapid industrialization and rapid urbanization, in the era of climate change, deforestation is increasing significantly, resulting in rising global surface temperatures. Forests are one of the key natural factors that control and decide the climate, weather patterns, and quantity of carbon dioxide and deforestation of an area exuberates the survival of living organisms such as humans, plants, and animals. Because of Anthropocentrism, globalization and excessive commoditization, the earth, people, and climate were completely destroyed to the core. In order to rejuvenate and save the blue planet from these disasters there is a need or demand posed to consider nature and its well-being. The article primarily focuses on the process of emphasizing the ecosystem's value through Deep Ecology in relation to Thomas Coraghessan Boyle's satirical dystopian novel A Friend of the Earth, which takes place in the near future, where global warming has devastatingly impacted the environment. And the article also intends to project Boyle's concern about environmental stewardship through the eco - warriors of the novel and his clarion call for his readers to save earth from imminent dangers.
\end{abstract}

Keywords-Anthropocentrism, Commoditization, Deep Ecology, Deforestation, Dystopian.

\section{INTRODUCTION}

Thomas Coraghessan Boyle is an American Novelist and Short story writer. He has published more than twenty-eight novels and more than 100 short stories. $\mathrm{He}$ received many literary awards including the PEN/Faulkner Award, the PEN/Malamud Prize, the PEN/West Literary Prize, the Commonwealth Gold Medal for Literature, National Academy of Arts and Letters Award for his prose excellence. T.C. Boyle, a Distinguished Professor Emeritus of English at the USC Dornsife College of Letters, Arts and Sciences, has won Henry Thoreau Prize for his literary excellence in nature writing. He likes writing about the environmental issues of his native California Channel Islands. In an interview with Robert Birnbaum, Boyle asserts that he wrote a dystopian novel A Friend of the Earth much inspired by Edward Abbey's work The Monkey Wrench Gang (Birnbaum
"Author Interview"). In addition to A Friend of the Earth (2000), Boyle's most significant works concerning environmental attention are World's End (1987), Tortilla Curtain (1995), and When the Killing's Done (2011).

T.C. Boyle's Science Fiction A Friend of the Earth (2000) is a speculative futurism novel that shows a sophisticated consistency with scientific discourses on climate change, species extinction and conservation of the environment. Tyrone O'Shaughnessy Tierwater, the auto diegetic narrator, tells of his future between 2025 and 2026, where the worst weather forced the animals to come out of their Pulchris mansion cages and they wreak havoc. In the third-person narrator, with flashbacks, Ty speaks of his history between 1989 and 1997 featuring Ty, Andrea, Teo and Sierra's environmentalist action centre, whose monkeywrenching is primarily against the Siskiyou logging operations. 


\section{DISCUSSION}

The dystopian novel A Friend of the Earth was examined using Naess' platform principles in order to analyse and illustrate humanity's anthropocentric attitude toward nonhuman nature. The novel addresses current environmental issues such as deforestation, mass extinction of species, global warming, climate change, and the depletion of natural resources, among others. By expressing his concern for the natural world and articulating their ecological sensitivity through fiction, the writer explores the human-nonhuman relationship

Arne Naess was a Norwegian philosopher who coined the term "Deep Ecology" and was a major intellectual and motivating figure in the environmental movement of the late twentieth century. Arne Naess and George Sessions agreed in 1984 on a deep ecology plan which has eight points and states that they will not be solved by technical solutions to existing ecological issues. In general, the Platform Principles list the most popular ideas among deep ecologists they agree with the most about. These Eight points of the Deep Ecology Platform are:

1. The flourishing of human and non-human life on Earth has intrinsic value. The value of non-human life forms is independent of the usefulness they may have for narrow human purposes.

2. Richness and diversity of life forms are values in themselves and contribute to the flourishing of human and non-human life on Earth.

3. Humans have no right to reduce this richness and diversity except to satisfy vital needs.

4. Present human interference with the nonhuman world is excessive, and the situation is rapidly worsening.

5. The flourishing of human life and cultures is compatible with a substantial decrease of the human population. The flourishing of human life requires such a decrease.

6. Significant change of life conditions for the betterment require change in policies. These affect basic economic, technological, and ideological structures.

7. The ideological change is mainly that of appreciating life quality (dwelling in situations of intrinsic value) rather than adhering to a high standard of living. There will be a profound awareness of the difference between big and great.
8. Those who subscribe to the foregoing points have an obligation directly or indirectly to participate in the attempt to implement the necessary changes. (Naess, 29)

The radical environmentalist characters Ty, Andrea and Sierra believe in the concept of "intrinsic value." Ty's eco consciousness exhibits when he explains why people preserve the environment: "We don't preserve the environment for the benefit of man, for progress, but for its own sake, because the whole world is a living organism and we are but a humble part of it" (FOE 194-195). Ty's emphasis on the preservation of nature makes the distinction between usefulness for humans which is an anthropocentric view. Dave Foreman argues that "[a]ll things have intrinsic value, inherent worth" and he focuses on the fact that the value of things cannot be determined by how much they "ring up on the cash register of the gross national product" whether they are good or not since "[t]hey are good because they exist"(3-4).

Ty is a former Eco-activist in the Earth Forever radical group! Believes in 'Live and Let Live' and serves as a focal point. When he walks through the forest of the Siskiyou Range, he feels the scent and tastes the warm woods in the air. This is a reflection of his unity with nature. In fact, he does not want the forest to be cleared, because logging is equivalent to 'being raped' (FOE 29). As a result, the planet will be 'stripped right down to the last stwig' (FOE 29). Jack D. Forbes takes it a step further and states that the rape of a woman, a land and a people are all the same as "the rape of the earth, the rape of the rivers, the rape of the forest, the rape of the air, the rape of the animals" because "[b]rutality knows no boundaries. Greed knows no limits" (xvi).

If a forest becomes a target of human violence, it will extinguish the trees and thus all the animals and plants living in it. Deforestation means that with the destruction of jungles, the abundance and variety of life forms will be extinguished. In addition, the loss of biodiversity in one part of the world impacts other parts of the world, directly or indirectly. In short, it has an effect on the world.These deformities are the consequences of the lack of an ecological self which values richness and diversity among different lives. Ty, Andrea, and Sierra's identification with the natural world, and their feeling of being at home in it, symbolizes their getting rid of the burden of the capitalistic society which dominates the world.

Population growth has an adverse effect on earth, as shown by Ty's focus on the world population of 2025 , eleven and a half billion, and 60 million people living in California alone. By Ty's point of view, the decline in human population will have a positive impact on living 
conditions. Ty, for instance, battled against General Electricity of San Fernando Valley, which wants to provide electricity to a large extent, slaughtered all the trees so far as the eye could see, and a chain of steel towers was installed. Ty wishes to prioritize the preservation of the abundance and diversity of life. For "all the lost and endangered animals" he wants to restore the past in 2026.

As Naess argues, a new ethics which welcomes plants, animals and humans at the same time to live in harmony with nature for the well-being of the world would be more efficient "if it were acted upon by people who believe in its validity, rather than merely its usefulness" (FOE 67). At this point, Ty's criticism of this world view is heard:

Try telling that [the fact that "the whole world is a living organism"] to the Axxam Corporation when they're clear cutting thousands of acres of old growth to pay down the junk-bond debt accrued in their hostile takeover of Coast Lumber, and you find yourself in a philosophical bind. They're going to cut, and Earth Forever! is going to stop them, any way they can. Hence Sierra, up in the tree. (FOE 194)

Ty and all other progressive, self-extended activists have made them act responsibly. Any kind of wound on earth requires a wound on their bodies, which drives them to take action to repair that wound. The group are full-fledged activists whose goal is to undermine the logging activities of the timber industry in the Pacific Northwest. One of their extreme acts of protest includes sabotaging activity of logging by digging a big pit in the middle of the night on the road used by the trucks.

Activist Sierra, Ty's daughter who has been protesting in a redwood tree at an altitude of one hundred and eighty feet above the ground for more than three years. Sierra is expected to suspend the Coast Lumber and Axxam logging businesses. In her extended self she feels a sense of responsibility, and Sierra reflects her ecological existence as expressed in the principle of ethical treatment not only of plants and animals, but also of rocks and dirt. Sierra parallels Julia Butterfly Hill's real-life protest, who spent over a year and a half in a redwood tree camp and remembers Rajasthan's Amrita Devi Bishnoi as a brave lady who sacrificed her life with 363 other Bishnoi for the protection of Kherji trees.

Ty's total union with all the living beings in the wilderness by welcoming scorpion's ticks, mites, [c]ougars, bears, rabid skunks. As for Andrea, Ty's wife, she is also in unison with all living and nonliving beings of the wilderness is an "expression of the love affair he was having with these mountains [the Sierra Nevada]" which Andrea is "as much in love with these mountains and this moment as he" (FOE 154) because they both embrace the mountains.

Ty criticizes the lifestyle of western consumers once he had and calls "my life when I was a criminal" before he's built an ecocentric lifestyle. He labels a person with a consumerist lifestyle as a "criminal" because he uses a lot of resources and leaves a large ecological footprint that is hazardous to earth's health. He proposes a simple life like that of Henry David Thoreau, who built a cabin and lived in Walden Pond near Concord, Massachusetts, for two years.Science and Technology alone will not be able to entirely eliminate environmental issues, philosophical intervention into human behaviour is required to incorporate ecosophy, or the ethics of values, and deep regard for nonhuman nature. Modern technology and industrial commercial activities obliterate humanity's interaction with the natural environment and create a big chasm between them. Ecotheologian Thomas Berry highlights the inculpation of deep ecological awareness in modern life by "accepting the fact that the life community, the community of all living species, is the greater reality and the greater value, and that the primary concern of the human must be the preservation and enhancement of this larger community" (Berry13)

As insisted in Deep Ecology's eight principle, one has to engage in the attempt to bring about the requisite environmental changes. For Foreman, passion and vision are two key factors in protecting the world from destruction. Action is the core and it is more serious than theory. He thinks that they have been too reasonable and calm, so it is time to "let rage flow at what the human cancer is doing to Earth, to be uncompromising" (Foreman 20). It is therefore humanity's greater responsibility to take care of Earth.

Mouchang Yu and Yi Lei in their article "Ethical Dimensions of the Environmental Crisis" states that "The root of the environmental crisis is closely related to ethics" and clearly point out that "Besides political, economic and technological causes, the environmental crisis is fundamentally a crisis of worldview and values" ( $\mathrm{Yu}$ and Lei 241). To build environmental consciousness, the lack of ecological wisdom or ecosophy in modern life necessitates a drastic transformation. Ecophilosophy promotes environmental awareness in human civilization by emphasising the relevance of ethical ideals, moral obligations, and care for nonhuman nature in order to bridge the enormous gap between humans and nonhumans. 
Many efforts are taken to attain the Sustainable Development Goals (SDGs) which is also known as the Global Goals by governments, the private sector, civil society and individuals. The Wildlands Project, The Arne Naess Selected Works Project, the Ecoagriculture Movement, the Ecoforestry Institute and Institute for Deep Ecology education programs, and the Ecostery Foundation are a few instances of deep ecology movement ideals being used to work in favour of biodiversity, wilderness preservation, and ecological restoration. Bioregionalism is also a sort of deep ecology activism.

\section{CONCLUSION}

To conclude, through the philosophy of deep ecology T.C. Boyle highlights radical environmentalist characters who direct a paradigm shift from anthropocentrism to ecocentrism in which the concept of society is not human-centred but includes human and nonhuman environments / entities. Nevertheless, in A Friend of the Earth, the eco-terrorists Ty, Andrea and Sierra comment on these basic ecological principles, look ecocentric and take responsibility for making significant improvements. According to Boyle, technology does not have any magical solution to environmental issues as that of Arnae Naess advocated as no one's philosophy and technology is important to the entire planet, the more diversity the more the earth is saved. To stop environmental disasters, Ty and other activists believe in the maxims "Live and Let Live" and "No Compromise in the Protection of Mother Earth," (FOE 8) act on behalf of their greater selves. The novel concludes with a positive statement that life's essence and diversity will find a way back. T.C.Boyle reawakens ecological awareness and embed in the minds of readers an environmental message of sustainable living. Therefore, Humanity can rejuvenate and maintain the Earth's biodiversity by upholding these profound ecological concepts.

\section{REFERENCES}

[1] Berry Thomas. The Viable Human. Deep Ecology for the Twenty-First Century, etd George Sessions, Shambhala Publications, 1995, pp. 13.

[2] Birnbaum, Robert. (2003). "Author Interview: T.C. Boyle." Identity Theory. 24 Jan. 2020. Retrived from www.identitytheory.com/tc-boyle/

[3] Boyle, T.C. (2001). A Friend of the Earth. London:Penguin Books.

[4] Forbes, Jack D. (2008). Columbus and Other Cannibals: The Wético Disease of Exploitation, Imperialism, and Terrorism.New York: Seven Stories Press.pp. xvi.

[5] Foreman, Dave. (1991). Confessions of an EcoWarrior.New York:Harmony Books. pp 3-4
[6] Naess, Arne, and George Sessions. "Platform Principles of the Deep Ecology Movement." The Deep Ecology Movement: An Introductory Anthology. Alan Drengson and Yuichi Inoue,Eds. Berkeley: North Atlantic Books, 1995,pp.29.

[7] $\mathrm{Yu}$, Mouchang\& Lei, Yi. Ethical Dimensions of the Environmental Crisis. Environment and Development, etd Teng Teng, Ding Yifan, ISBN: 978-1-84826-270-6 (eBook). pp 240- 246. 